\title{
Celebrity Endorsement and Purchase Intention: A Structural Equation Modeling Approach
}

\author{
Sajeeb Kumar Shrestha*
}

\begin{abstract}
This study tries to measure the impact of celebrity endorsement on purchase intention in Kathmandu City. Structured questionnaires were as administered to collect data. 200 samples were taken. Structure Equation Modeling was applied via EFA, CFA and SEM to refine the constructs, to validate the measurement model and to test hypotheses of structural model. This research confirmed that similarity, matching and familiarity of endorser's are the major factors for increasing purchase intention in Kathmandu City. No support was established for expertise and trustworthiness to enhance purchase intention. This study contributes in marketing research that how celebrity influences purchase intention towards endorsed products or services.
\end{abstract}

Key Words: Celebrity endorsement, Kathmandu City, SEM.

\section{Introduction}

Celebrity endorsement is the show-off of famous personalities in the advertisements to promote the brand (McCracken, 1986). Celebrity on advertisement influences our everyday life pattern (Shimp, 2008). Using celebrity in the advertisement is becoming very popular (Pringle, 2004; Till \& Busler, 1998). Celebrity endorsement makes a product more visible in the markets. It increases brand recall value (Ohanian, 1991; O'Mahony \& Meenaghan, 1997). Celebrity endorsement helps to boost brain recall (Misra \& Beatty, 1990).

Purchase intention means the chance of purchasing the product (Burton, Lichtenstein, Netemeyer, \& Garreston, 1998). It is the consumer's plan for buying the product in future (Spears \& Singh, 2004). It is the cognitive behavior of consumers to buy particular product (Ling, Chai, \& Piew, 2010).In the purchase situation, consumer's interest, information and evaluation to the product were the important factors that direct purchase intention (Laroche, Kim, \& Zhou, 1996). World- of-mouth communication affects purchase intention of a product. Consumer examines product features, price, and celebrity performance for making intention to purchase (Sheu, 2010). Popularity and image of the celebrity also affect the brand being purchased when consumer perceives celebrity as a reference group to inspire (Staff,2011).

* Dr. Shrestha is Associate Professor at Tribhuvan University, Faculty of Management, Shanker Dev Campus Email:drsajeeb@gmail.com 
Consumer's purchase intention is affected by his admired celebrities in the positive direction.

Marketers believe that celebrity endorsement draws attention, increasing trust towards brand, and builds credibility that is resulted into higher sales (Sheu, 2010). Different advertising appeals are used to create interests of consumer that will support in purchase intention (Ling et al., 2010). Marketers allocate more resources to establish their brand. Marketers endorse celebrity and communicate sponsored message to different media to make familiar their brand (Apejoye, 2013). Celebrity endorsement is the important aspect of modern advertising these days. Celebrity endorsement contributes to return of marketing investment in advertising (Apejoye, 2013). Company expects good financial benefit in return after celebrity endorsement. It is perceived that celebrity endorsement is the winning formula in marketing and brand management strategically (Prasad, 2012; Mukherjee, 2009). Celebrity endorsement creates instant brand awareness, supports to establish the brand and increase brand recall (Morwitz, 2014). Matching right product to right celebrity increase the brand value (Morwitz, 2014). Celebrities are high profile personalities so they are endorsed in brand (Erodogan, Baker \&Tagg, 2001). Celebrity endorsement promotes to set the trend in the markets that help to increase purchase intention in endorsed brand (Martin \& Bush, 2000).

Endorsing celebrity is an expensive task but company can get more benefits through for celebrity endorsement (Malik, \& Qureshi, 2017)). Consumers perceive it is of high quality if endorsed celebrity. Endorsed brand draws quick attention. Media exposure is dynamically increased. Endorsed brand could get more visible in the market. Company could get financial return (Erdogan et al., 2001; Farrell, Karles, Montfort, \& McClatchey, 2000). Celebrity endorsed product could be differentiated easily from competitors (Burroughs \& Feinber, 1987; Solomon, Bamossy, Askegaard, \& Hogg, 2006). Celebrity endorsement has positive direct impact on purchase intention (Karina, 2008).

Similarity is the likeness between the source and the receiver of the message (McGuire, 1985). It is the same as between the consumer and the endorser (Erdogan, 1999). When consumers and celebrity have some common factors in their interests and lifestyle, better bonding is formed (Erdogan, 1999). Celebrities are selected based on their background similar with consumers. Empathy between celebrity and consumers is created through endorsement (Belch \& Belch, 2001). Company may choose a common man whom the consumers identify more easily and feel comfortable.

Expertise means celebrity is perceived as authentic for the product. Celebrity's professional background and skills help to support their claims toward the products more convincing. It is said the celebrity with expertise will be more important than their physical attractiveness (Till \& Busler, 1998). When consumers perceive celebrity as expert, they agree highly to the celebrity's recommendations (Ohanian, 1991). How celebrity is perceived as a source of expertise can calculate the effectiveness of endorsement. 
Matching between celebrity and the product or the company is an important aspect of celebrity endorsement (Cooper, 1984; Forkan, 1980). Good matching between celebrity and the product will positively transfer meaning to the consumers and to enhance brand personality (Rockney \& Green, 1979). More congruence with celebrity and the product fosters good brand image than less congruent celebrity and the product (Kotler, 1997). Matching has two things - the perceived fit and the image of the celebrity (Misra \& Beatty, 1990).

Trustworthiness is the reliability of the message an endorser communicates to the target markets and consumers perceived it as valid (Hovland, \& Weiss, 1953). It is consumers' confidence towards source that endorsement provides message honestly (Ohanian, 1991). Miller and Baseheart (1969) argued when consumers perceive message is highly trustworthy, message would be more convincing for changing attitude of consumers. McGinnies and Ward (1980) asserted that consumer's perceived trustworthiness has changed attitudes more than perceived expertise. If celebrity was endorsed to many products, his or her presence would be less credible and trustworthy than endorsed to only one product (Tripp, Jensen \& Carlson, 1994). If the celebrities were blamed for negative way, their endorsement made harmful to product (Louie \& Obermiller, 2002).

Brand familiarity means consumer know the brand very well. Consumers purchase those brands that are familiar to them. Brand image and brand experiences are important factors for consumers purchase intention (Baker, \& Churchill, 1977; Low \& Lamb Jr., 2000). Brand image is resides very deeply in the mind of consumers and cannot be override by other advertising endorsements (Baker, \& Churchill, 1977; Low \& Lamb Jr., 2000). But in the condition of price hike, consumers might look for alternate brand having similar characteristics to their familiar brand (d'Astous \& Gargouri, 2001). Sometimes price moderates familiarity to purchase intentions.

Rachbini (2018) conducted a research on the influence of celebrity endorsements on purchase intention in smart phones. It was found that expertiseand trustworthiness influence purchase intention in smart phones. Baniya (2017) measured celebrity endorsement affecting brand loyalty of Nepalese consumers. The study confirmed source expertise and matching has positive influence purchase intention.

Samarasinghe (2017) conducted a research on effectiveness of celebrity endorsement on social media towards consumer's purchase intention in FMCG. It was confirmed that sourceexpertise, trustworthiness, and familiarity influence purchase intention. Impact of source expertise, trustworthiness, and familiarity is subject to male and female consumers. Muthukumar (2014) investigated on the impact of celebrity endorsement through TV medium. It was found that the matching and purchase intention go hand in hand.

It is common these days using popular celebrity in promoting products in the markets and increasing sales. Endorsement is promoted through television, radio, magazines, and social media frequently. It is expected that celebrity endorsement will generate financial 
return to the company. But sometimes it is hard to achieve marketing objectives. So, this research is designed to measure the impact of celebrity endorsement on purchase intention in Kathmandu City. There is lack of research done in celebrity endorsement and purchase intention methodologically to validate the theory in the Nepalese context.

The research questions were raised in the following:

What are the factors affecting celebrity endorsements on purchase intention?

Which factor of celebrity endorsement influences mostly on purchase intention?

The objective of the study is as follows:

To examine the factors affecting celebrity endorsement on purchase intention.

To measure most influential factor of celebrity endorsement on purchase intention?

Figure 1: Research Framework

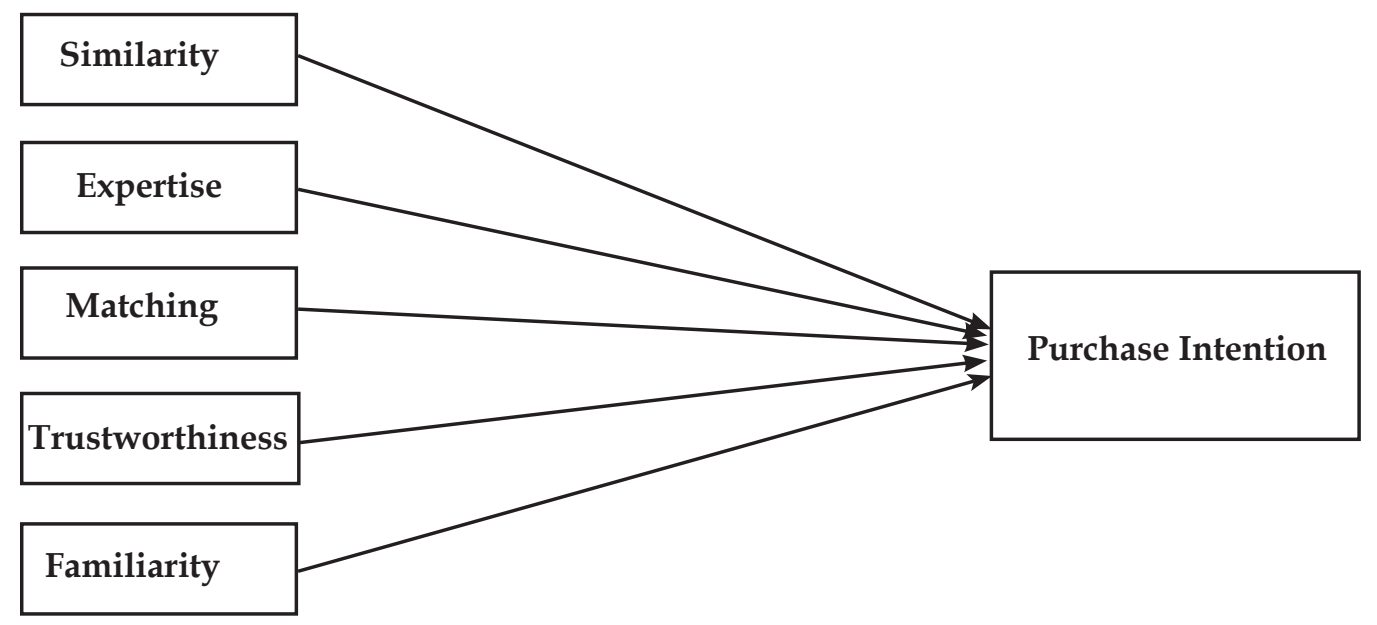

\section{Research Hypothesis}

H1: Similarity positively affects purchase intension

H2: Expertise positively affects purchase intension

H3: Matching positively affects purchase intension

H4: Trustworthiness/credibility positively affects purchase intension

H5: Familiarity positively affects purchase intension

\section{Methodology}

Descriptive and Causal research design was used to achieve the objectives (Malhotra \& Birks, 2006). Descriptive research design explains the constructs relating to marketing thoroughly (Malhotra \& Birks, 2006; Zikmund, 2000). Causal research design tests the hypothesis or tests cause and effect. 
Research subject of this study was people who reside in the Kathmandu City and continuously purchasing branded goods for a year.Judgmental sampling was included in this survey that respondent who has purchased at least one celebrity endorsed products within one month was the sample of this study. Survey was administered within Kathmandu City only. 200 samples were included in this research which is large enough (Kline, 2011). Kline argued sample less than 100 are small samples, between 100 to 200 samples are considered as medium sample and more than 200 samples are said to be large sample. Sample between 100 to 200 are sufficient to get meaningful results of the study (Eldred, 1987).

Primary data were collected through structured questionnaires based on Likert-scales. A Likert scale is anchored on " 1 - Strongly Disagree" to "5-Strongly Agree). Constructs existed in this research instruments were similarity, expertise, matching, trustworthiness, and familiarity as exogenous constructs and purchase intention as endogenous constructs. Demographic variables were gender, age, qualification and income included in the survey instrument.

This study showed that 52 percent of the respondents were male and 48 percent of the respondents were female. Majority of the respondents having bachelor degree graduates having 39 percent and higher secondary having 26 percent. Large numbers of respondents were expressing 75 percent on 20 to 30 years category, followed by 11 percent in 30 to 40 years. Majority of the respondents having income between Rs. 20, 000 to Rs. 30,000 representing 27 percent followed by income between Rs. 30,000-Rs. 40,000 representing 28 percent.

Structural Equation Modeling (SEM) was used as EFA (Exploratory Factor Analysis), CFA (Confirmatory Factor Analysis) and SEM to generate and refine constructs, to confirm constructs and to test the hypotheses. SPSS 20 and AMOS 20 software were used for SEM purpose.

\section{EFA}

Exploratory Factor Analysis (EFA) is used at the initial stage of research where researcher wants to extract constructs or refinement of the constructs from customer point of view (Hair, Anderson, Tatham \& Black, 1998). EFA is a tool to develop theory in a considerable way. But it does not confirm the theory. EFA is an important tool before CFA (Confirmatory Factor Analysis). Bartlett's test of Sphericity (Chi-square 3226.080) that is significant (p-value $=0.000<0.05$ ) and $\mathrm{KMO}$ value was 0.769 . This expressed that sample adequacy criteria were met for further analysis.

Six constructs were extracted having total effect of 68 percent of variance. Individual scale items more than 0.5 were linked into relevant constructs. Factor one was said as Similarity, factor two was Expertise, factor three was called Matching, factor four as Trustworthiness, factor five was Purchase Intention and factor six was Familiarity. It is shown in Table 1. 
Table 1: Rotated Component Matrix

\begin{tabular}{|c|c|c|c|c|c|c|}
\hline \multicolumn{7}{|c|}{ Rotated Component Matrix } \\
\hline & \multicolumn{6}{|c|}{ Component } \\
\hline & Similarity & Expertise & Matching & Trustworthiness & $\begin{array}{l}\text { Purchase } \\
\text { Intention }\end{array}$ & Familiarity \\
\hline $\operatorname{sim} 5$ & .787 & & & & & \\
\hline $\operatorname{sim} 4$ & .769 & & & & & \\
\hline $\operatorname{sim} 3$ & .751 & & & & & \\
\hline $\operatorname{sim} 2$ & .696 & & & & & \\
\hline $\operatorname{sim} 1$ & .639 & & & & & \\
\hline exp5 & & .815 & & & & \\
\hline exp3 & & .729 & & & & \\
\hline $\exp 4$ & & .729 & & & & \\
\hline $\exp 2$ & & .670 & & & & \\
\hline mat5 & & & .763 & & & \\
\hline mat4 & & & .753 & & & \\
\hline tru2 & & & & .734 & & \\
\hline tru1 & & & & .613 & & \\
\hline tru3 & & & & .594 & & \\
\hline pin6 & & & & & .794 & \\
\hline pin5 & & & & & .689 & \\
\hline pin3 & & & & & .542 & \\
\hline fam5 & & & & & & .841 \\
\hline fam4 & & & & & & .612 \\
\hline $\begin{array}{l}\text { Extract } \\
\text { Rotatic }\end{array}$ & $\begin{array}{l}\text { Tethod: Pri } \\
\text { thod: Vari }\end{array}$ & $\begin{array}{l}\text { cipal Com } \\
\text { ax with K }\end{array}$ & $\begin{array}{l}\text { nent Anal } \\
\text { er Norma }\end{array}$ & $\begin{array}{l}\text { is. } \\
\text { ation. }\end{array}$ & & \\
\hline
\end{tabular}

\section{Confirmatory Factor Analysis (CFA)}

Confirmatory factor analysis is run to test the validity and reliability of the model proposed in the research context. It confirms where the relation between measured variables and manifest variables exist or not. CFA shows the fitness of the proposed model and validity of the measurement model (Anderson \& Gerbing, 1988). The proposed model in this research was fairly fitted as, $\mathrm{CMIN} / \mathrm{DF}=3.066, \mathrm{GFI}=.893 ; \mathrm{CFI}=.902, \mathrm{AGFI}=.873$, and $\mathrm{RMR}=.070$, and RMSEA = 0.052 (Byrne, 2001; Hair et al., 1998; Joreskog \& Sorbom, 1993). It was confirmed that the model was fairly fitted. 
Figure 2: Measurement Model

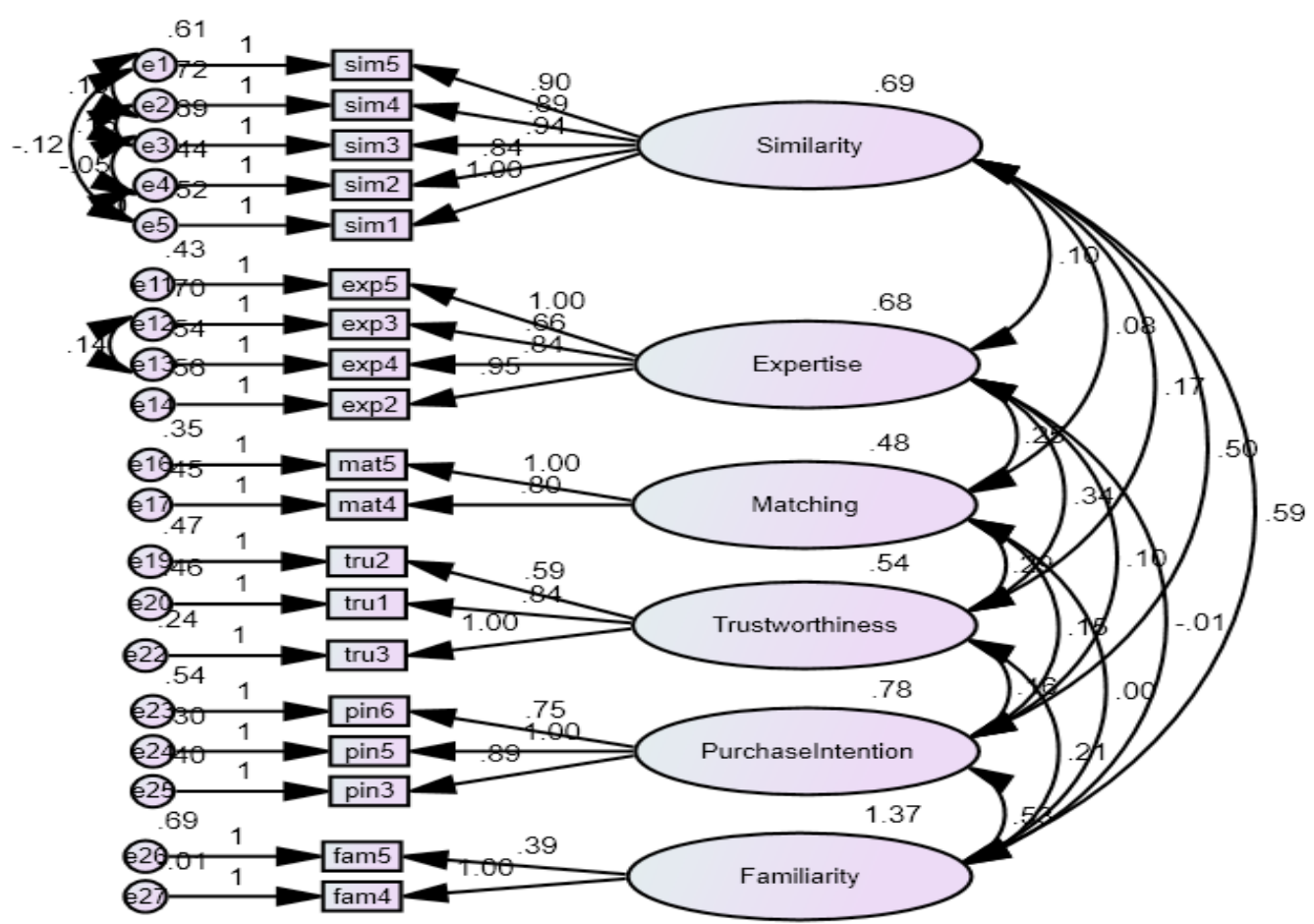

Research model must be valid in the research context. To test the validity, discriminant validity and convergent validity were checked for the measurement model. AVE (Average Variance Explained) should be greater than 0.5 which means measurement model contains discriminant validity (Fornell \& Larcker, 1981). For obtaining construct validity, AVE should be greater than MSV (Maximum Shared Variance) and ASV (Average Shared Variance). These criteria were met for the measurement model in Figure 2. That's why, the model was valid.

\section{Structural Equation Modeling (SEM)}

Structural equation modeling is a multivariate tool to measure the many structural relationships among exogenous and endogenous constructs (Structural equation modeling, 2017). SEM is the extension of regression analysis tool so that many causal models are tested simultaneously. It is used to test the hypotheses of the structural model. SEM is run after model has been passed through CFA. It is shown in Figure 3. 
Figure 3: Structural Model

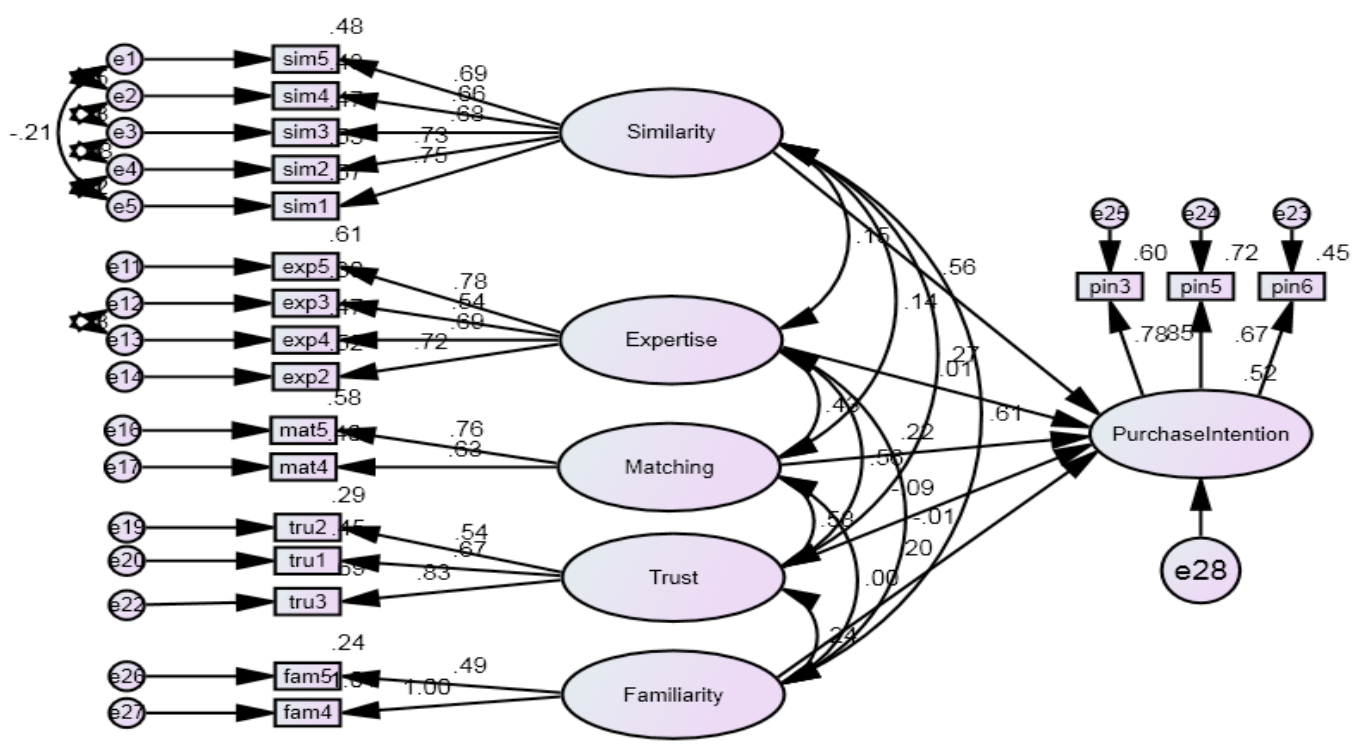

\section{Squared Multiple Correlations}

Squared multiple correlation of purchase intention (.52 or 52 percent) was reported. This model estimated by the independent variables was 52 percent.

\section{Hypothesis Testing}

Relationship among celebrity endorsements constructs and purchase intention construct were tested in Table 2 .

Table 2: Relation between Celebrity Endorsement and Purchase Intention

\begin{tabular}{|c|c|c|c|c|c|c|c|}
\hline Hypothesis & $\begin{array}{c}\text { Endogenous } \\
\text { Constructs }\end{array}$ & $\begin{array}{c}\text { Exogenous } \\
\text { Construct }\end{array}$ & Estimate & S.E. & C.R. & P & Label \\
\hline H1 & Purchase Intention & Similarity & .596 & .109 & 5.464 & $* * *$ & Accepted \\
\hline H2 & Purchase Intention & Expertise & .010 & .093 & .106 & .916 & $\begin{array}{c}\text { Not } \\
\text { Accepted }\end{array}$ \\
\hline H3 & Purchase Intention & Matching & .281 & .133 & 2.117 & .034 & Accepted \\
\hline H4 & Purchase Intention & Trustworthiness & -.112 & .133 & -.842 & .400 & $\begin{array}{c}\text { Not } \\
\text { Accepted }\end{array}$ \\
\hline H5 & Purchase Intention & Familiarity & .150 & .072 & 2.078 & .038 & Accepted \\
\hline
\end{tabular}

Table 2 showed the regression coefficient of similarity, matching and familiarity on purchase intention were found statistically significant. So, H1, H3 and H5 were accepted. 
Regression coefficient of expertise and trustworthiness on purchase intention were not statistically significant. So, $\mathrm{H} 2$ and $\mathrm{H} 4$ were not accepted.

It was said that similarity, matching and familiarity were the major factors for purchase intention.

\section{Conclusion}

The research was conducted to analyze the impact of celebrity endorsement on purchase intention in Kathmandu City. Similarity, matching and familiarity of endorser's are the major factors for creating purchase intention in Kathmandu City. No support was found for expertise and trustworthiness to create purchase intention.

This study is contrast with Rachbini (2018) that expertise and trustworthiness does not influence purchase influence. It is because Nepalese markets are growing at product and selling marketing and marketing activities are focused to sell the products than brand building. This study is partially consistent with Baniya (2017) that matching influence purchase intention. This study is partially consistent with Samarasinghe (2017) that familiarity influence purchase intention. This study is consistent with Muthukumar (2014) that matching and purchase intention works together.

Similar bonding between consumers and celebrity in their interest and lifestyle increases the purchase intention. Endorsement creates empathy between consumers and celebrity that will influence on purchase of the brand endorsed. Matching is very important between celebrity and the product being endorsed. This gives cues to consumers in the markets. Proper matching between celebrity and the product creates brand personality that will affect purchase intention. It's very common that consumer purchase that brand which is very similar to them. A positive brand image reside in the mind of consumers supports to purchase the brand again and again so it's comfortable for marketers to make familiarity in the endorsement.

Celebrity endorsement resides basically on consumer part, consumers' connection with celebrity is the factors of purchase intention rather endorser's expertise and trustworthiness.

\section{References}

Anderson, J.C., \& Gerbing, D.W. (1988). Structural equation modeling in practice: A review and recommended two-step approach. Psychological Bulletin, 103(3), 411-423.

Apejoye, A. (2013). Influence of celebrity endorsement of advertisement on students' purchase intention. Journal of Mass Communication \& Journalism, 3(3), 1-7.

Baker, M. J., \& Churchill, M. A. (1977). The impact of physical attractiveness models on advertising evaluation. Journal of Marketing Research, 14, 538-555.

Baniya, R. (2017). Components of celebrity endorsement affecting brand loyalty of Nepali customers. Journal of Business and Management Research, 2(1), 52-65. 
Belch, G., \& Belch, M. (2001). Introduction to advertising and promotion: An integrated marketing communications perspectives (3rd ed.). Irwin: Homewood.

Burroughs, J. W., \& Feinber, R. A. (1987). Using response latency to assess spokesperson effectiveness. Journal of Consumer Research, 14(2), 295-299.

Burton, S., Lichtenstein, D. R., Netemeyer, R. G., \& Garreston, J. A. (1998). A scale for measuring attitude towards private label products and an examination of its psychological and behavioral correlates. Journal of the Academy of Marketing Science, 26(4), 293-306.

Byrne, B.M. (2001). Structural equation modeling with AMOS: Basic concepts, applications and programming. Mahwah, N. J.: Lawrence Erlbaum Associates.

Cooper, M. (1984). Can celebrities really sell product? Marketing and Media Decisions, 19(3), 64-65.

d'Astous, A., \& Gargouri, E. (2001). Consumer evaluations of brand limitations. European Journal of Marketing, 35(1/2), 153-232.

Eldred, G. (1987). Real estate: Analysis and strategy. New York: Harper \& Row

Erdogan, B. Z. (1999). Celebrity endorsement: A literature review. Journal of Marketing Management, 15(4), 291-314.

Erodogan, B. Z., Baker, J., \& Tagg, S. (2001). Selecting celebrity endorsers: The practioner's perspective. Journal of Advertising Research, 41(3), 39-48.

Farrell, K.A., Karles, G.V., Montfort, K.W., \& McClatchey, C. A. (2000). Celebrity performance and endorsement value: The case of Tiger Woods. Managerial Finance, 26(7), 1-15.

Forkan, J. (1980). Product matchup key to effective star presentation. Advertising Age, 51(6), 42-58.

Fornell, C., \& Larcker, D. F. (1981). Evaluating structural equation models with unobservable variables and measurement error. Journal of Marketing Research, 18(2), 39-50.

Hair, J. F. Jr., Anderson, R. E., Tatham, R. L., \& Black, W. C. (1998). Multivariate data analysis. NJ: Prentice Hall.

Hovland, C. I., \& Weiss, W. (1953). The Influence of Source Credibility on Communication Effectiveness. Public Opinion Quarterly, 15, 635-650. http://dx.doi. org/10.1086/266350

Joreskog, K., \& Sorbom, D. (1993). LISREL 8: Structural equation modeling with the IMPLIS command language. Chicago: Scientific Software International (SSI).

Karina, P. R. (2008). Apparel brand endorsers and their effects on purchase intentions: A study of Philippine consumer. Philippine Management Review, 15, 83-99.

Kline, R.B. (1998). Principles and practice of structural equation modeling. New York: The Guilford Press. 
Kotler, P. (1997). Marketing management: Analysis, planning, implementation and control (9th ed.). Prentice-Hall, Upper Saddle River.

Laroche, M., Kim, C., \& Zhou, L. (1996). Brand familiarity and confidence as determinants of purchase intention: An empirical test in a multiple brand context. Journal of Business Research, 37(2), 115-120.

Ling, K. C., Chai, L. T., \& Piew, T. H. (2010). The effects of shopping orientations, online trust and prior online purchase experience toward customers' online purchase intention. International Business Research, 3(3), 63-76.

Louie, T.A., \& Obermiller, C. (2002). Consumer response to a firm's endorser (Dis) association decisions. Journal of Advertising, 31(4), 41-52.

Low, G. S., \& Lamb Jr., C. W. (2000). The measurement and dimensionality of brand associations. Journal of Product and Brand Management, 9(6), 350-368.

Malhotra, N. K., \& Birks, D. F. (2006). Marketing research: An applied approach (2nd European ed.). FT Prentice Hall. Financial times.

Malik, H. M., \& Qureshi, M. M. (2017). The Impact of Celebrity Endorsement on Consumer Buying Behavior. Advances in Social Sciences Research Journal, 4(3), 159-170.

Martin, C. A., \& Bush, A. J. (2000). Do role models influence teenagers' purchase intentions and behavior? Journal of Consumer Marketing, 17(5), 441-454.

McCracken, G. (1986). Culture and consumption: A theoretical account of the structure and movement of the cultural meaning of consumer goods. Journal of Consumer Research, 13(1), 71-81

McGinnies, E., \& Ward, C. (1980). Better liked than right: Trustworthiness and expertise in credibility. Personality and Social Psychology Bulletin, 6, 467-472.

McGuire, W. J. (1985). Attitudes and attitude change in handbook of social psychology. In G. Lindzey and E. Aronson (Eds.), Handbook of social psychology (233-346). NY, New York: Random House.

Miller, G. R., \& Baseheart, J. (1969). Source trustworthiness, opinionated statements, and response to persuasive communication, Speech Monograph, 36(1), 1-7. DOI: $10.1080 / 03637756909375602$

Misra, S., \& Beatty, S. E. (1990). Celebrity spokesperson and brand congruence: An assessment of recall and affect. Journal of Business Research, 21(2), 159-173.

Morwitz, V. (2014). Consumer's purchase intentions and their behavior. Foundation and Trend in Marketing, 7(3), 181-230.

Mukherjee, D. (2009). Impact of celebrity endorsements on brand image. Retrieved from https:/ / ssrn.com/abstract=1444814 or http:/ / dx.doi.org/10.2139/ssrn.1444814

Muthukumar, N. (2014). Celebrity endorsement through TV medium: A study with reference to Virudhunagar District, 1-283 
Ohanian, R. (1991). The impact of celebrity spokesperson's perceived image on consumer's intention to purchase. Journal of Advertising Research, 31(1), 46-52.

O'Mahony, S., \& Meenaghan, T. (1997). The impact of celebrity endorsements on consumers. Irish Marketing Review, 10(2), 15-24.

Prasad, J. (2012). Brand endorsement by celebrities impacts towards customer satisfaction. African Journal of Business Management, 7(35), 3630-3635.

Pringle, H. ( 2004). Celebrity sells. England: John Wiley \& Sons Ltd.

Rachbini, W. (2018). The influence of celebrity endorsements on purchase intention: A study on Vivo V7. IOSR Journal of Business and Management, 20(8), 59-66.

Rockney, E. A., \& Green, W. F. (1979, October). Celebrities in TV commercials: Do they pay their way. Advertising Research Foundation, 25

Samarasinghe, U. S. (2017). Effectiveness of celebrity endorsement on social media towards consumer's purchase intention. Retrieved from https://www.researchgate.net/ publication/318253098_Effectiveness_of_Celebrity_Endorsement_on_Social_ Media_towards_Consumer's_Purchase_Intention

Sheu, J. B. (2010). A hybrid dynamic forecast model for analyzing celebrity endorsement effects on consumer attitudes. Mathematical and Computer Modelling, 52(9), 1554-1569. https://doi.org/10.1016/j.mcm.2010.06.020

Shimp, T. A. (2008). Advertising, promotion and other aspects of integrated marketing communications. Mason, Ohio: South Westen Cengage Learning.

Solomon, M., Bamossy, G., Askegaard, S., \& Hogg, M. K. (2006). Consumer behavior: A European perspective (5th ed.). NJ, New Jersey: Prentice Hall.

Spears, N., \& Singh, S. (2004). Measuring attitude towards the brand and purchase intention. Journal of Current Issue and Research in Advertising, 26(2), 53-66.

Staff, F. (2011). Hollywood's most trustworthy celebrities. Retrieved from https://www. forbes.com/2011/02/07/most-trustworthy-celebrities-business entertainment. html\#7cb9acca1bb5

Structural equation modeling (2017). Retrieved from http://www.statisticssolutions.com/ structural-equation-modeling/

Till, B., \& Busler, M. (1998). Matching products with endorsers: Attractiveness versus expertise. Journal of Consumer Marketing, 15(6), 576-586. https://doi. org/10.1108/07363769810241445

Tripp, C., Jensen, T. D., \& Carlson, L. (1994). The effects of multiple product endorsements by celebrities on consumers' attitudes and intentions. Journal of Consumer Research, 20(4), 535-547.

Zikmund, W. G. (2000). Business research methods. Fort Worth: The Dryden Press. 